\title{
Pemanfaatan Asystasia gangetica (L.) T. Anderson sebagai Biomulsa untuk Meningkatkan Laju Infiltrasi pada Lahan Kelapa Sawit Menghasilkan
}

\section{The Roles of Asystasia gangetica (L.) T. Anderson as Biomulch to Increase Soil Infiltration Rate on Mature Oil Palm Plantation}

\author{
Rahmi Khalida ${ }^{1}$, Dwi Guntoro ${ }^{2 *}$, dan Hariyadi ${ }^{2}$ \\ ${ }^{1}$ Program Studi Agronomi dan Hortikultura, Sekolah Pascasarjana, Institut Pertanian Bogor \\ ${ }^{2}$ Departemen Agronomi dan Hortikultura, Fakultas Pertanian, Institut Pertanian Bogor \\ (IPB University), Jl. Meranti, Kampus IPB Darmaga, Bogor 16680, Indonesia
}

Diterima 4 Oktober 2021/Disetujui 27 Desember 2021

\begin{abstract}
Planting cover crop or biomulch as one of land conservation methods could be applied to increase the availability of groundwater. Asystasia gangetica is a plant that has the potential as biomulch on mature oil palm plantations. This research aimed to determine the roles of $\underline{A}$. gangetica increasing water availability by improving the infiltration rate. The research was conducted on Cikabayan Experimental Field IPB from August 2020 to January 2021. The treatments were types of biomulch consisting of without biomulch, $\underline{\text {. gangetica, }}$ Ageratum conyzoides, Borreria alata, and Arachis pintoi which were arranged using a randomized block design with five replications. The biomulches were planted on plots $5 m \times 2 m$. The results showed

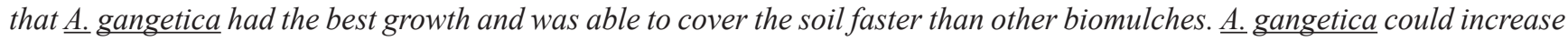
the infiltration rate by $42 \%$ compared to without biomulch treatment with infiltration capacity of $20.42 \mathrm{~cm}$ per hour at 20 weeks after planting (WAP).
\end{abstract}

Keywords: cover crop, land conservation, water availability

\section{ABSTRAK}

Penanaman tanaman penutup tanah atau biomulsa dilakukan sebagai upaya konservasi lahan untuk meningkatkan ketersediaan air tanah. Asystasia gangetica merupakan tumbuhan yang berpotensi sebagai biomulsa pada lahan kelapa sawit menghasilkan. Penelitian ini bertujuan mengetahui potensi $\underline{A}$. gangetica dalam peningkatan ketersediaan air melalui peningkatan laju infiltrasi. Penelitian dilaksanakan di Kebun Percobaan Cikabayan IPB pada Agustus 2020 hingga Januari 2021. Perlakuan terdiri atas tanpa biomulsa, A. gangetica, Ageratum conyzoides, Borreria alata dan Arachis pintoi yang dirancang menggunakan rancangan kelompok lengkap teracak (RKLT) satu faktor dengan lima ulangan. Masing-masing

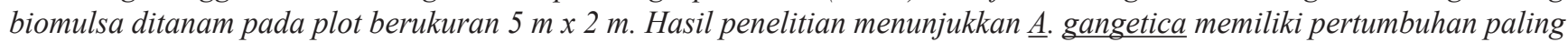
baik dan mampu menutup tanah lebih cepat dibandingkan biomulsa lainnya. A. gangetica dapat meningkatkan laju infiltrasi sebesar $42 \%$ dibandingkan tanpa biomulsa dengan kapasitas infiltrasi sebesar $20.42 \mathrm{~cm}$ per jam pada 20 minggu setelah tanam (MST).

Kata kunci: ketersediaan air, konservasi lahan, tanaman penutup tanah

\section{PENDAHULUAN}

Kelapa sawit merupakan komoditas perkebunan dengan penggunaan lahan terluas di Indonesia. Perkebunan kelapa sawit memiliki luas areal mencapai $14,326,350$ ha pada tahun 2018 (Ditjenbun, 2019). Widodo dan Dasanto (2010) melaporkan salah satu dampak dari perluasan areal perkebunan kelapa sawit adalah semakin berkurangnya ketersediaan air. Penggunaan lahan-lahan marjinal dengan ketersediaan air dan hara yang tidak seimbang berpengaruh

* Penulis untuk korespondensi. e-mail: dwi_guntoro@ipb.ac.id terhadap produksi kelapa sawit. Kelapa sawit membutuhkan curah hujan sebesar 2,000 mm-2,500 mm sepanjang tahun dengan distribusi merata tanpa adanya bulan kering yang nyata (Arsyad et al., 2012). Penggunaan lahan-lahan marjinal dengan penyerapan air hujan yang rendah menyebabkan ketersediaan air berkurang. Cekaman kekeringan terjadi apabila curah hujan $<1250 \mathrm{~mm}$ per tahun dan defisit air $>200 \mathrm{~mm}$. Defisit air sebanyak $486 \mathrm{~mm}$ dan $426 \mathrm{~mm}$ di Riau dan Jambi menyebabkan penurunan produktivitas kelapa sawit semester 1 tahun 2016 masing-masing sebesar $14.96 \%$ dan $33.79 \%$ dibandingkan produktivitas semester 1 tahun sebelumnya (Darlan et al., 2015). 
Pengoptimalan lahan untuk perkebunan kelapa sawit terutama dalam menjaga ketersediaan air dapat dilakukan melalui metode konservasi tanah secara vegetatif, yaitu penanaman tanaman penutup tanah atau biomulsa (Wahyudi, 2014). Indonesian Sustainable Palm Oil Certification System (ISPO) mencamtukan bahwa konservasi lahan dengan adanya tanaman penutup tanah merupakan indikator dari pengelolaan dan pemantauan lingkungan di perkebunan kelapa sawit (Kementan, 2015). Dengan adanya biomulsa, konservasi tanah dan air diupayakan melalui pencegahan terhadap erosi tanah (Arsyad, 2010), meningkatkan kelembaban tanah (Alonso-Ayuso et al., 2018; Asbur dan Ariyanti, 2017), serta meningkatkan kapasitas infiltrasi (Gao-lin et al., 2016; Sharma et al., 2018). Penggunaan Arachis pintoi sebagai biomulsa di perkebunan kelapa sawit belum menghasilkan dapat meningkatkan kandungan air tanah hingga 27.39\% (kedalaman 0-10 cm) (Yuniarti et al., 2018).

Biomulsa umumnya digunakan pada lahan kelapa sawit belum menghasilkan. Sebagian besar biomulsa yang ditanam berasal dari famili Leguminoseae. Akan tetapi, beberapa tanaman dari jenis tersebut kurang tahan naungan (Baligar dan Fageria, 2007). Asystasia gangetica merupakan salah satu tanaman yang kini banyak diteliti potensinya untuk dimanfaatkan sebagai biomulsa pada lahan kelapa sawit menghasilkan. A. gangetica merupakan salah satu vegetasi dominan yang sering ditemukan di lahan kelapa sawit menghasilkan (Satriawan dan Fuady 2019). A. gangetica dapat meningkatkan ketersediaan hara tanah melalui dekomposisi serasah yang cepat (Asbur et al., 2018a), menambah cadangan karbon tanah hingga 119\% (Satriawan et al., 2020) serta meningkatkan stabilitas agregat tanah (Junedi et al., 2015). Akan tetapi, belum banyak penelitian terkait potensi $A$. gangetica dalam menjaga ketersediaan air terutama dalam peningkatan laju infiltrasi. Infiltrasi berhubungan dengan kadar air tanah dan simpanan air bawah tanah (Arsyad, 2010). Informasi terkait infiltrasi dibutuhkan dalam pengelolaan irigasi atau evalusi keseimbangan neraca air pada suatu lahan. Oleh karena itu, diperlukan penelitian lebih lanjut untuk mengetahui peran A. gangetica sebagai biomulsa dalam meningkatkan laju infiltrasi pada lahan kelapa sawit menghasilkan.

\section{BAHAN DAN METODE}

Penelitian dilaksanakan di Kebun Percobaan Kelapa Sawit Cikabayan IPB umur 12 tahun dengan jarak tanam segitiga sama sisi (9 m x 9 m x 9 m) pada Agustus 2020 hingga Januari 2021. Curah hujan rata-rata saat penelitian adalah $232 \mathrm{~mm}$ per bulan dan rata-rata kelembaban udara sebesar $82.52 \%$. Data curah hujan dan kelembaban udara diperoleh dari Stasiun Klimatologi Bogor yang berjarak 3.6 $\mathrm{km}$ dari lokasi penelitian.

Penelitian ini dirancang menggunakan rancangan kelompok lengkap teracak (RKLT) faktor tunggal yang terdiri atas lima perlakuan, yaitu tanpa biomulsa, $A$. gangetica, Ageratum conyzoides, Borreria alata, dan Arachis pintoi. Penelitian dilakukan dalam lima ulangan dan satuan percobaan berupa plot berukuran $5 \mathrm{~m} \mathrm{x} 2 \mathrm{~m}$ sebanyak 25 petak yang berada di tengah-tengah gawangan hidup kelapa sawit. Biomulsa ditanam dengan jarak tanam $20 \mathrm{~cm} \times 20 \mathrm{~cm}$. Bahan tanam $A$ gangetica dan $B$. alata menggunakan stek batang dengan panjang 2 ruas, $A$. pinto $i$ dengan stek batang 4 ruas, sementara $A$. conyzoides berasal dari bibit cabutan yang diambil di sekitar Kebun Percobaan Cikabayan dengan tinggi $5 \mathrm{~cm}$.

Pengamatan tinggi tanaman dan jumlah daun diambil dari 10 tanaman contoh dari masing-masing perlakuan. Persentase penutupan tanah dihitung menggunakan kuadran $0.5 \mathrm{~m} \times 0.5 \mathrm{~m}$ yang di dalamnya terdapat lubang-lubang kecil berukuran $5 \mathrm{~cm}$ x $5 \mathrm{~cm}$, kuadran dilempar secara acak sebanyak dua kali pada setiap plot. Panjang akar, indeks luas daun dan biomassa diamati dari plot destruktif sebanyak lima titik untuk lima kali pengamatan yang berada pada plot utama berukuran $20 \mathrm{~cm}$ x $20 \mathrm{~cm}$. Pengamatan panjang akar dilakukan dengan mengambil tanaman secara utuh dari dalam tanah kemudian akar diukur dari pangkal sampai ujung akar terpanjang. Indeks luas daun diperoleh dari perbandingan antara luas daun total yang diukur menggunakan ImageJ dengan luas lahan yang ditutupi tanaman. Pengamatan bobot kering biomassa dilakukan dengan menimbang bobot kering tanaman dengan menimbang semua bagian tanaman (akar dan tajuk) setelah tanaman dioven selama 2 hari dengan suhu $80^{\circ} \mathrm{C}$.

Pengukuran infiltrasi tanah dilakukan pada 8-20 minggu setelah tanam (MST) menggunakan double ring infiltrometer. Penurunan air ke dalam tanah dicatat per menit hingga penurunan air konstan. Laju infiltrasi lapang/aktual dari setiap perlakuan diperoleh dari rata-rata penurunan air tiap menit selama 3 jam. Rumus yang digunakan dalam perhitungan laju infiltrasi (Budianto, 2014) yaitu: $f=\Delta H / t$ [f: Laju infiltrasi (cm per jam); $\Delta \mathrm{H}$ : Tinggi penurunan air dalam waktu 3 jam (cm); t: Waktu yang dibutuhkan oleh air pada $\Delta \mathrm{H}$ untuk masuk ke tanah (jam)]. Kapasitas infiltrasi dihitung berdasarkan waktu infiltrasi konstan dengan rumus infiltrasi Horton (Beven, 2004): $f=f c+(f 0-f c)$ $\mathrm{e}^{-k t}$ [f : Kapasitas infiltrasi pada waktu $\mathrm{t}$ ( $\mathrm{cm}$ per jam); fc: Laju infiltrasi pada waktu konstan (cm per jam); f0 : Laju infiltrasi awal (cm per jam); e : 2.718; k: konstanta untuk tanah/koefisien infiltrasi; $\mathrm{t}$ : Waktu untuk mencapai infiltrasi konstan (jam). Nilai $\mathrm{k}$ diperoleh dari persamaan $\mathrm{k}=-1 /(\mathrm{m}$ $\log$ e), m merupakan gradien persamaan linier regresi dari hubungan antara laju infiltrasi aktual (f) dengan log (f-fc)]. Data hasil pengamatan dianalisis secara statistik dengan sidik ragam (ANOVA) dan uji lanjut Duncan Multiple Range Test (DMRT) pada taraf nyata 5\%.

\section{HASIL DAN PEMBAHASAN}

\section{Pertumbuhan Biomulsa}

Panjang tanaman A. gangetica $67.59 \mathrm{~cm}$ pada 20 MST dengan rata-rata pertumbuhan $3.29 \mathrm{~cm}$ per minggu, nyata lebih tinggi dibandingkan $A$. conyzoides, B. Alata, dan $A$. pintoi (Tabel 1). Hasil penelitian menunjukkan pertumbuhan $A$. gangetica tergolong cepat dibandingkan biomulsa lainnya di bawah kondisi ternaungi. A. gangetica dilaporkan merupakan salah satu vegetasi dominan pada 
lahan kelapa sawit umur 13 tahun dan 18 tahun di Lampung dengan tingkat intensitas cahaya rendah yang berkisar antara 974.2-985.4 lux dan 675.4-843.1 lux (Asbur et al., 2018b). Tinggi $A$. gangetica tidak memiliki perbedaan yang nyata pada kebun kelapa sawit umur 6,7, dan 8 tahun pada jarak tanam $20 \mathrm{~cm}$ x $20 \mathrm{~cm}$ (Satriawan et al. (2020) dan nyata lebih tinggi dibandingkan Nephrolepis biserrata, Paspalum conjugatum, dan $A$. conyzoides di bawah naungan kelapa sawit umur 20 tahun (Asbur et al., 2018a).

A. gangetica memiliki rata-rata jumlah daun sebanyak 40.4 helai pada $20 \mathrm{MST}$ dan rata-rata pertambahan jumlah daun 2.5 helai per minggu, nyata lebih tinggi dibandingkan A. conyzoides, B. alata, dan A. pintoi (Tabel 1). Hal tersebut sejalan dengan Asbur et al. (2018a) yang menyatakan $A$. gangetica memiliki jumlah daun lebih banyak dibandingkan A. conyzoides dan $P$. conjugatum. Akan tetapi, menurut Satriawan et al. (2020) tingkat naungan berpengaruh terhadap pertambahan jumlah daun A. gangetica, yaitu semakin tinggi tingkat naungan maka pertumbuhan daun semakin terhambat.

Pertumbuhan akar A. gangetica sepanjang $39.34 \mathrm{~cm}$ pada pengamatan $20 \mathrm{MST}$, nyata lebih tinggi dibandingkan biomulsa lainnya (Tabel 1). Panjang akar A. gangetica yang lebih tinggi berkorelasi positif dengan tingginya penyerapan unsur hara dibandingkan terhadap biomulsa lainnya. Asbur et al. (2018a) menyatakan serapan hara $\mathrm{N}$ dan $\mathrm{P}$ pada $A$. gangetica lebih tinggi dibandingkan dengan $A$. conyzoides dan $P$. conjugatum. Hal tersebut menunjukkan $A$. gangetica lebih responsif terhadap pemberian $\mathrm{N}$ sehingga pertumbuhan akar sebagai salah satu organ vegetatif lebih baik.

Indeks luas daun (ILD) merupakan salah satu indikator pertumbuhan penting bagi tanaman terutama dalam penutupan tanah. Hasil penelitian menunjukkan $A$. gangetica memiliki ILD sebesar 9.21 pada $20 \mathrm{MST}$, nyata lebih tinggi dibandingkan ILD biomulsa lainnya (Tabel 2). Hal ini diduga dipengaruhi oleh jumlah daun biomulsa $A$. gangetica yang lebih tinggi sehingga luas daun $A$. gangetica juga lebih besar dibanding biomulsa lainnya. Asbur (2016) menyatakan bertambahnya jumlah daun per tanaman akan menyebabkan total luas daun per tanaman bertambah luas karena adanya korelasi sangat nyata di antara keduanya.

A. gangetica mampu menutup tanah hingga $100 \%$ pada 20 MST dengan rata-rata laju penutupan tanah $6.40 \%$ per minggu. Penutupan tanah oleh $A$. gangetica lebih cepat dibandingkan terhadap biomulsa lainnya dan perbedaan penutupan tersebut sudah terlihat sejak 8 MST (Gambar 1; Gambar 2). Kecepatan penutupan tanah dipengaruhi oleh indeks luas daun (Sarjono et al., 2019). A. gangetica memiliki indeks luas daun (ILD) tertinggi dibandingkan terhadap biomulsa pembandingnya. Akan tetapi, kemampuan $A$. gangetica dalam menutup tanah secara cepat dikhawatirkan berdampak negatif terhadap pertumbuhan tanaman di sekitarnya melalui kejadian kompetisi maupun alelopati. A. gangetica dikenal sebagai tumbuhan invasif karena dapat mengokupasi dan mendominasi vegetasi pada ekosistem baru. Suzuki et al. (2019) melaporkan A. gangetica menghasilkan zat alelopati berupa indol3-karboksaldehid dan (6R,9S)3-oxo- $\alpha$-ionol yang dapat menghambat pertumbuhan selada, rumput jajagoan, dan rumput timothy. Asbur (2016) menyatakan pengendalian sifat invasif tersebut dapat dilakukan melalui pemangkasan tajuk mengikuti rotasi pengendalian gulma di kebun kelapa sawit. Hasil pangkasan yang terdekomposisi disimpan sebagai cadangan karbon di dalam tanah serta meningkatkan kandungan bahan organik dan hara tanah.

A. gangetica memiliki bobot kering biomassa sebesar $36.74 \mathrm{~g} 0.04 \mathrm{~m}^{-2}$ yang nyata lebih tinggi dibandingkan biomulsa lainnya (Tabel 2). Tingginya bobot kering biomassa $A$. gangetica dipengaruhi oleh banyaknya jumlah daun dan luas total daun. Peningkatan jumlah daun dan luas total daun tersebut akan meningkatkan laju fotosintesis tanaman sehingga biomassa tanaman yang diukur dari bobot basah maupun kering akan dihasilkan lebih banyak (Sumiahadi et al., 2016).

\section{Laju Infiltrasi}

Infiltrasi merupakan proses meresapnya air ke dalam tanah secara vertikal. Laju infiltrasi adalah banyaknya air yang masuk per satuan waktu melalui permukaan tanah (Arsyad, 2010). Hasil penelitian menunjukkan laju infiltrasi air aktual pada lahan yang ditamami biomulsa nyata lebih tinggi dibandingkan terhadap lahan tanpa biomulsa pada $8 \mathrm{MST}$ hingga $20 \mathrm{MST}$ (Tabel 3). Sarjono et al. (2019) menyatakan perlakuan A. pintoi sebagai biomulsa di perkebunan kelapa sawit belum menghasilkan dapat meningkatkan laju infiltrasi air $32.47 \%$ lebih tinggi dibanding perlakuan vegetasi alami pada $20 \mathrm{MST}$. Agusta et al. (2020) juga menyatakan peningkatan infiltrasi air tanah pada lahan kelapa sawit meningkat setelah adanya tanaman

Tabel 1. Rata-rata tinggi, jumlah daun, dan panjang akar biomulsa di lahan kelapa sawit menghasilkan pada 20 MST

\begin{tabular}{lcccccc}
\hline \multirow{2}{*}{ Biomulsa } & \multicolumn{2}{c}{ Tinggi tanaman $(\mathrm{cm})$} & \multicolumn{2}{c}{ Jumlah daun (helai) } & \multicolumn{2}{c}{ Panjang akar $(\mathrm{cm})$} \\
\cline { 2 - 7 } & $20 \mathrm{MST}$ & $\begin{array}{c}\text { Rata-rata per } \\
\text { minggu }\end{array}$ & $20 \mathrm{MST}$ & $\begin{array}{c}\text { Rata-rata per } \\
\text { minggu }\end{array}$ & $\begin{array}{c}\text { 20 MST } \\
\text { Rata-rata per } \\
\text { minggu }\end{array}$ \\
\hline A. gangetica & $67.59 \mathrm{a}$ & $3.29 \mathrm{a}$ & $40.4 \mathrm{a}$ & $2.5 \mathrm{a}$ & $39.34 \mathrm{a}$ & $1.61 \mathrm{a}$ \\
A. conyzoides & $12.54 \mathrm{c}$ & $0.36 \mathrm{c}$ & $9.0 \mathrm{c}$ & $0.2 \mathrm{~b}$ & $18.40 \mathrm{c}$ & $0.77 \mathrm{~b}$ \\
B. alata & $29.53 \mathrm{~b}$ & $1.18 \mathrm{bc}$ & $18.0 \mathrm{~b}$ & $0.6 \mathrm{~b}$ & $36.90 \mathrm{a}$ & $1.57 \mathrm{a}$ \\
A. pintoi & $32.33 \mathrm{~b}$ & $1.50 \mathrm{~b}$ & $18.4 \mathrm{~b}$ & $0.8 \mathrm{~b}$ & $18.40 \mathrm{c}$ & $0.68 \mathrm{~b}$ \\
\hline
\end{tabular}

Keterangan: Angka yang diikuti huruf yang sama pada kolom yang sama tidak berbeda nyata berdasarkan DMRT pada taraf $\alpha=5 \%$ 
Tabel 2. Indeks luas daun (ILD), penutupan tanah, dan bobot kering biomassa biomulsa di lahan kelapa sawit menghasilkan pada $20 \mathrm{MST}$

\begin{tabular}{lcccc}
\hline \multirow{2}{*}{ Biomulsa } & \multicolumn{2}{c}{ ILD } & \multicolumn{2}{c}{ Bobot kering biomassa $\left(\mathrm{g} 0.04 \mathrm{~m}^{-2}\right)$} \\
\cline { 2 - 5 } & $20 \mathrm{MST}$ & Rata-rata per minggu & $20 \mathrm{MST}$ & Rata-rata per minggu \\
\hline A. gangetica & $9.21 \mathrm{a}$ & $0.67 \mathrm{a}$ & $36.74 \mathrm{a}$ & $2.59 \mathrm{a}$ \\
A. conyzoides & $0.81 \mathrm{~b}$ & $0.04 \mathrm{~b}$ & $8.25 \mathrm{~b}$ & $0.51 \mathrm{~b}$ \\
B. alata & $1.18 \mathrm{~b}$ & $0.04 \mathrm{~b}$ & $12.96 \mathrm{~b}$ & $0.73 \mathrm{~b}$ \\
A. pintoi & $1.27 \mathrm{~b}$ & $0.08 \mathrm{~b}$ & $19.18 \mathrm{~b}$ & $1.27 \mathrm{~b}$ \\
\hline
\end{tabular}

Keterangan: Angka yang diikuti huruf yang sama pada kolom yang sama tidak berbeda nyata berdasarkan DMRT pada taraf $\alpha=5 \%$

penutup tanah Mucuna bracteata dan Pueraria javanica dengan laju infiltrasi masing-masing sebesar $35.46 \mathrm{~cm}$ per jam dan $32.40 \mathrm{~cm}$ per jam.

Rata-rata laju infiltrasi aktual pada plot $A$. gangetica adalah $57.19 \mathrm{~cm}$ per jam pada 20 MST (Tabel 3). $A$. gangetica dapat meningkatkan laju infiltrasi air sebesar $42 \%$ dibandingkan tanpa biomulsa pada 20 MST. Peran biomulsa dalam meningkatkan laju infiltrasi air dipengaruhi oleh pertumbuhan akar. Penetrasi akar ke dalam tanah dapat memperbaiki struktur tanah dan meningkatkan pori-pori tanah sehingga laju air masuk ke dalam tanah lebih cepat (Sarjono et al., 2019). Peningkatan bobot akar vegetasi berbanding lurus dengan peningkatan laju infiltrasi dan pengisian air tanah (Musdalipa et al., 2018). A. gangetica yang ditanam pada penelitian memiliki panjang dan bobot akar yang lebih tinggi dibandingkan terhadap biomulsa lainnya. Laju infiltrasi air juga dipengaruhi kandungan bahan organik yang diperoleh dari hasil dekomposisi biomulsa. Bahan organik dapat meningkatkan porositas dan kestabilan struktur tanah sebagai hasil dari perannya dalam pembentukan agregat tanah yang menyebabkan jumlah pori dan aktivitas mikroba tanah meningkat (Utomo et al., 2015; Wawan et al., 2019). Porositas dan stabilitas struktur tanah yang baik dapat meningkatkan laju peresapan air ke dalam tanah (Irawan dan Yuwono, 2016).

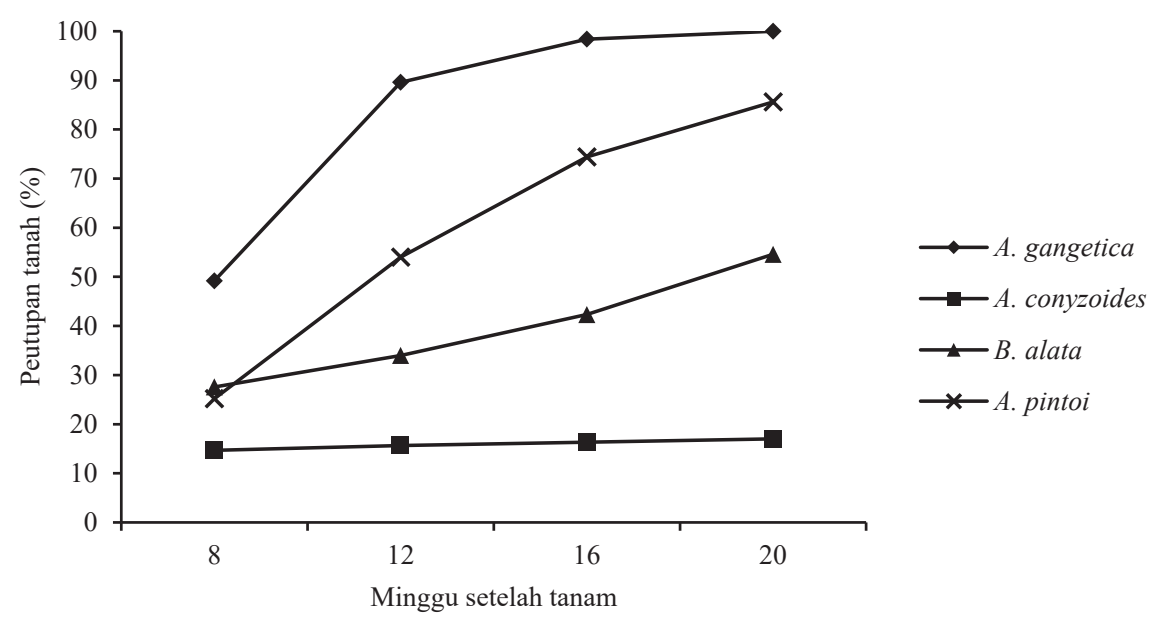

Gambar 1. Persentase penutupan tanah oleh biomulsa di lahan kelapa sawit menghasilkan

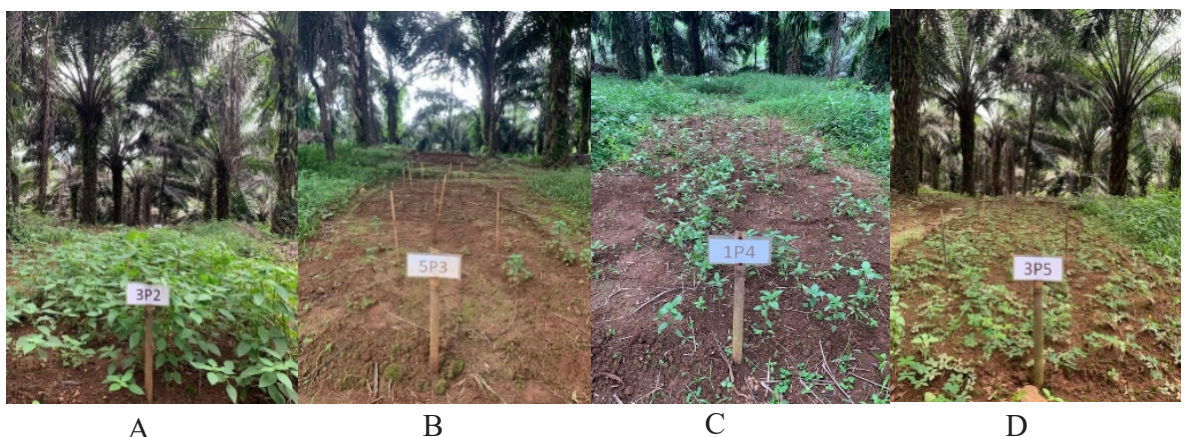

Gambar 2. Penutupan tanah oleh biomulsa di lahan kelapa sawit menghasilkan pada 20 MST. (A) A. gangetica; (B) A. conyzoides; (C) B. alata; (D) A. pintoi 
Tabel 3. Rata-rata laju infiltrasi air pada berbagai biomulsa di lahan kelapa sawit menghasilkan pada 20 MST*

\begin{tabular}{lllll}
\hline \multirow{2}{*}{ Perlakuan } & \multicolumn{4}{c}{ Laju infiltrasi (cm per jam) } \\
\cline { 2 - 5 } & $8 \mathrm{MST}$ & $12 \mathrm{MST}$ & $16 \mathrm{MST}$ & $20 \mathrm{MST}$ \\
\hline Tanpa biomulsa & $25.69 \mathrm{~d}$ & $34.99 \mathrm{bc}$ & $38.72 \mathrm{~b}$ & $33.10 \mathrm{~d}$ \\
A. gangetica & $44.94 \mathrm{a}$ & $48.56 \mathrm{a}$ & $50.46 \mathrm{a}$ & $57.19 \mathrm{a}$ \\
A. conyzoides & $32.03 \mathrm{c}$ & $33.97 \mathrm{c}$ & $37.74 \mathrm{~b}$ & $38.29 \mathrm{c}$ \\
B. alata & $35.03 \mathrm{bc}$ & $36.17 \mathrm{bc}$ & $37.51 \mathrm{~b}$ & $39.66 \mathrm{c}$ \\
A. pintoi & $38.55 \mathrm{~b}$ & $39.45 \mathrm{~b}$ & $40.68 \mathrm{~b}$ & $46.07 \mathrm{~b}$ \\
\hline
\end{tabular}

Keterangan: Angka yang diikuti huruf yang sama pada kolom yang sama tidak berbeda nyata berdasarkan DMRT pada taraf $\alpha=5 \%$. MST= Minggu setelah tanam. *waktu pengamatan selama 3 jam

\section{Kapasitas Infiltrasi}

Kapasitas infiltrasi merupakan laju maksimum air yang dapat masuk ke dalam tanah pada suatu saat ketika laju infiltrasi berjalan konstan. Kapasitas infiltrasi ditentukan oleh tekstur tanah, ukuran pori dan kemantapan pori, serta kandungan air tanah (Arsyad, 2010). Laju infiltrasi konstan dicapai masing-masing perlakuan dalam waktu yang berbeda. Plot $A$. gangetica mencapai keadaan konstan paling lama dibandingkan terhadap perlakuan lainnya baik pada 8 MST maupun 20 MST. Hasil penelitian menunjukkan kapasitas infiltrasi air pada seluruh biomulsa mengalami peningkatan dari awal hingga akhir pengamatan, kecuali pada $A$. conyzoides yang mengalami penurunan pada 20 MST. Kapasitas infiltrasi pada lahan yang ditanami biomulsa nyata lebih tinggi dibandingkan dengan lahan tanpa biomulsa. Kapasitas infiltrasi pada perlakuan A. gangetica dan $A$. pintoi tidak berbeda nyata, yaitu masing-masing sebesar $20.42 \mathrm{~cm}$ per jam dan $20.84 \mathrm{~cm}$ per jam pada 20 MST (Tabel 4). Kapasitas infiltrasi tersebut tergolong cepat

Tabel 4. Rata-rata kapasitas infiltrasi air pada berbagai biomulsa di lahan kelapa sawit

\begin{tabular}{llccccc}
\hline $\begin{array}{l}\text { Waktu } \\
\text { Pengamatan }\end{array}$ & \multicolumn{1}{c}{ Perlakuan } & $\mathrm{fc}(\mathrm{cm}$ per jam) & $\mathrm{f0}(\mathrm{cm}$ per jam) & $\mathrm{k}$ & $\mathrm{t}(\mathrm{jam})$ & $\begin{array}{c}\text { Kapasitas infiltrasi } \\
\text { (cm per jam) }\end{array}$ \\
\hline 8 MST & Tanpa biomulsa & 4.78 & 124.18 & 1.03 & 2.83 & $11.35 \mathrm{c}$ \\
& A. gangetica & 12.60 & 240.40 & 1.30 & 3.00 & $17.34 \mathrm{a}$ \\
& A. conyzoides & 9.22 & 149.56 & 1.16 & 2.66 & $15.72 \mathrm{~b}$ \\
& B. alata & 12.81 & 154.02 & 1.52 & 2.75 & $15.03 \mathrm{~b}$ \\
& A. pintoi & 9.80 & 172.38 & 1.15 & 3.00 & $15.08 \mathrm{~b}$ \\
$12 \mathrm{MST}$ & Tanpa biomulsa & 7.48 & 122.52 & 1.10 & 2.75 & $13.18 \mathrm{c}$ \\
& A. gangetica & 12.47 & 233.07 & 1.23 & 2.83 & $19.39 \mathrm{a}$ \\
& A. conyzoides & 11.19 & 150.88 & 1.30 & 2.50 & $16.72 \mathrm{~b}$ \\
& B. alata & 11.16 & 141.95 & 1.24 & 2.66 & $16.06 \mathrm{~b}$ \\
& A. pintoi & 10.50 & 167.90 & 1.13 & 2.75 & $17.68 \mathrm{ab}$ \\
& Tanpa biomulsa & 9.39 & 129.36 & 1.16 & 2.46 & $16.38 \mathrm{c}$ \\
& A. gangetica & 12.57 & 222.82 & 1.22 & 2.75 & $20.07 \mathrm{a}$ \\
& A. conyzoides & 11.98 & 140.83 & 1.32 & 2.41 & $17.40 \mathrm{bc}$ \\
& B. alata & 12.22 & 129.52 & 1.24 & 2.45 & $17.95 \mathrm{~b}$ \\
& A. pintoi & 11.65 & 138.38 & 1.22 & 2.31 & $19.30 \mathrm{a}$ \\
& Tanpa biomulsa & 10.80 & 139.40 & 1.14 & 2.25 & $15.10 \mathrm{c}$ \\
& A. gangetica & 12.86 & 199.41 & 1.21 & 2.66 & $20.42 \mathrm{a}$ \\
& A. conyzoides & 12.62 & 100.46 & 1.63 & 2.25 & $16.05 \mathrm{c}$ \\
& B. alata & 12.74 & 101.99 & 1.18 & 2.33 & $18.53 \mathrm{~b}$ \\
& A. pintoi & 11.80 & 116.60 & 1.38 & 2.00 & $20.84 \mathrm{a}$ \\
\hline
\end{tabular}

Keterangan: Angka yang diikuti huruf yang sama pada kolom yang sama tidak berbeda nyata berdasarkan DMRT pada taraf $\alpha=5 \%$. MST = Minggu setelah tanam; $\mathrm{fc}=$ Laju infiltrasi konstan; $\mathrm{f0}=$ Laju infiltrasi awal; $\mathrm{k}=$ Koefisien infiltrasi; $\mathrm{t}=$ Waktu infiltrasi konstan 
berdasarkan klasifikasi kapasitas infiltrasi air menurut Lee (1980). Jenis tanah dominan di lokasi penelitian merupakan inceptisol dengan kelas tekstur lempung liat berdebu (Hati dan Susila, 2016), sehingga tergolong memiliki kecepatan laju infiltrasi sedang (Budianto et al., 2014). Peningkatan kapasitas infiltrasi diduga karena aktivitas perakaran dari biomulsa yang dapat meningkatkan porositas tanah (Sarjono et al., 2019). A. gangetica memiliki perakaran lebih panjang dibandingkan biomulsa lainnya sedangkan $A$. pintoi membentuk banyak perakaran yang tumbuh di setiap bukunya.

\section{KESIMPULAN}

A. gangetica dapat dimanfaatkan sebagai biomulsa pada lahan kelapa sawit menghasilkan karena memiliki pertumbuhan paling baik di bawah naungan dan mampu menutup tanah lebih cepat dibandingkan terhadap $A$. conyzoides, B. alata, dan A. pintoi. A. gangetica dapat meningkatkan laju infiltrasi air tanah hingga $42 \%$ dibandingkan tanpa biomulsa. Plot A. gangetica memiliki laju infiltrasi sebesar $57.19 \mathrm{~cm}$ per jam dan kapasitas infiltrasi yang tergolong cepat, yaitu $20.42 \mathrm{~cm}$ per jam pada 20 MST.

\section{DAFTAR PUSTAKA}

Agusta, H., G.C. Handoyo, M.T. Sudaryanto, Hendrayanto. 2020. Cover crop and frond piles for improving soil water infiltration in oil palm plantation. IOP Conf. Ser.: Earth Environ. Sci. 460:1-6.

Alonso-Ayuso, M., J.L. Gabriel, I. García-González, J.P. Del Montea, M. Quemada. 2018. Weed density and diversity in a long-term cover crop experiment background. Crop Prot. 112:103-111.

Arsyad, A.R., H. Junedi, Y. Farni. 2012. Pemupukan kelapa sawit berdasarkan potensi produksi untuk meningkatkan hasil tandan buah segar (TBS) pada lahan marginal Kumpeh. J. Pen. UNJA. 14:29-36.

Arsyad, S. 2010. Konservasi Tanah dan Air. IPB Press, Bogor, ID.

Asbur, Y. 2016. Peran Asystasia gangetica (L.) T. Anderson dalam konservasi tanah dan neraca hara di perkebunan kelapa sawit menghasilkan. Disertasi. Sekolah Pascasarjana. Institut Pertanian Bogor. Bogor.

Asbur, Y., M. Ariyanti. 2017. Peran konservasi tanah terhadap cadangan karbon tanah, bahan organik, dan pertumbuhan kelapa sawit (Elaeis guineensis Jacq.). J. Kultivasi 16:402-411.

Asbur, Y., R.D.H. Rambe, Y. Purwaningrum, D. Kusbiantoro. 2018a. Potensi beberapa gulma sebagai tanaman penutup tanah di perkebunan kelapa sawit menghasilkan. J. Pen. Kelapa Sawit. 26:113-128.
Asbur, Y., Y. Purwaningrum, M. Ariyanti. 2018b. Vegetation composition and structure under mature oil palm (Elaeis guineensis Jacq.) stands. hal 254-260. Dalam Nurhayati, S.A. Udin, M. Asaad, M.F. Hassan, S. Mongkolkiastri, M. Lubis, G.H. Mardini (Eds.). Proceedings of the 7th International Conference on Multidisciplinary Research (ICMR 2018). Medan 56 September 2018.

Baligar, V.C., N.K. Fageria. 2007. Agronomy and physiology of tropical cover crops. J. Plant Nutr. 30:1287-1339.

Beven, K. 2004. Robert E. Horton's perceptual model of infiltration processes. Hydrol process. 18:34473460 .

Budianto, P.T.H., R. Wirosoedarmo, B. Suharto. 2014. Perbedaan laju infiltrasi pada lahan hutan tanaman industri pinus, jati dan mahoni. J. Sumberdaya Alam Lingkungan. 1:1-24.

Darlan, N. H., I. Pradiko, Winarna, H.H. Siregar. 2016. Dampak El Nio 2015 terhadap performa tanaman kelapa sawit di Sumatera bagian tengah dan selatan. J. Tanah dan Iklim. 40:113-120.

[Ditjenbun] Direktorat Jenderal Perkebunan. 2019. Statistik perkebunan Indonesia 2018-2020 kelapa sawit. http:// ditjenbun.pertanian,go.id [2 Agustus 2021].

Gao-Lin, W., Y. Zheng, C, Zheng, L. Yu, F. No-Fang, S. Zhi-Hua. 2016. Mixed artificial grasslands with more roots improved mine soil infiltration capacity. J. Hydrol. 535:54-60.

Hati, H.A.P., A.D. Susila. 2016. Optimasi dosis pemupukan kalium pada budidaya tomat (Lycopersicon esculentum) di inceptisol Dramaga. Bul. Agrohorti. 4:173-179.

Irawan, T., S.B. Yuwono. 2016. Infiltrasi pada berbagai tegakan hutan di arboretum Universitas Lampung. J. Sylva Lestari. 4:21-34.

Junedi, H., N. Myrna, E. Fathia. 2015. Peningkatan kemantapan agregat tanah pada ultisol melalui aplikasi ara sungsang [Asystasia gangetica (L.) T. Anders.]. hal 843-849. Dalam S. Herlinda, Suwandi, Tanbisyakur, D. Nursyamsi, M. Noor, S. Anwar, J. Barus, A.D. Sasanti, Puspitahati, M.I. Syafutri (Eds.). Prosiding Seminar Nasional Lahan Suboptimal 2015. Palembang 8-9 Oktober 2015.

[Kementan] Kementerian Pertanian. 2015. Sistem sertifikasi kelapa sawit berkelanjutan Indonesia (Indonesian Sustainable Palm Oil Certification System/ISPO). http://perundangan.pertanian.go.id [28 Agustus 2019]. 
Musdalipa, A., Suhardi, S.N. Faridah. 2018. Pengaruh sifat fisik tanah dan sistem perakaran vegetasi terhadap imbuhan air tanah. J. AgriTechno. 11:35-39.

Lee, R. 1980. Forest Hidrology. Gadjah Mada University Press, Yogyakarta, ID.

Sarjono, A., D. Guntoro, Supijatno. 2019. The role of biomulch Arachis pintoi in increasing soil infiltration rate on sloping land of oil palm plantation. J. Trop. Crop Sci. 5:89-95.

Sarjono, A., D. Guntoro, Supijatno. 2019. Perbandingan Arachis pintoi dengan tanaman kacang-kacangan penutup tanah lain dalam menekan laju erosi pada lahan kelapa sawit berbukit. J. Agron. Indonesia 47:90-96.

Satriawan, H., Z. Fuady. 2019. Short communication: analysis of weed vegetation in immature and mature oil palm plantations. Biodiversitas 20:3239-3298.

Satriawan, H., Z. Fuady, Ernawita. 2020. The potential of Asystasia intrusa weed of Acanthaceae family as a cover crop in oil palm plantations. Biodiversitas 21:5710-5717.

Sharma, P., A. Singh, C.S. Kahlon, A.S. Brar, K.K. Grover, M. Dia, R.L. Steiner. 2018. The role of cover crops towards sustainable soil health and agriculture: A review paper. Am. J. Plant Sci. 9:1935-1941.

Sumiahadi, A., M.A. Chozin, D. Guntoro. 2016. Evaluasi pertumbuhan dan perkembangan Arachis pintoi sebagai biomulsa pada budidaya tanaman di lahan kering tropis. J. Agron. Indonesia 44:98-103.
Suzuki, M., M.A. Chozin, A. Iwasaki, K. Suenaga, H. KatoNoguchi. 2019. Phytotoxic activity of chinese violet (Asystasia gangetica (L.) T. Anderson) and two phytotoxic substances. Weed Biol. Manag. 19:3-8.

Utomo, B.S., Y. Nuraini, Widianto. 2015. Kajian kemantapan agregat tanah pada pemberian beberapa jenis bahan organik di perkebunan kopi robusta. J. Tanah Sumberdaya Lahan. 2:111-117.

Wahyudi. 2014. Teknik konservasi tanah serta implementasinya pada lahan terdegradasi dalam kawasan hutan. J. Sains Teknologi Lingkungan. 6:71-85.

Wawan, I.R. Dini, Hapsoh. 2019. The effect of legume cover crop Mucuna bracteatai on soil physical properties, runoff and erosion in three slopes of immature oil palm plantation. IOP Conf. Ser.: Earth Environ. Sci. 250:012021.

Widodo, I.S., B.D. Dasanto. 2010. Estimasi nilai lingkungan perkebunan kelapa sawit ditinjau dari neraca air tanaman kelapa sawit (studi kasus: perkebunan kelapa sawit di Kecamatan Dayun, Kabupaten Siak, Propinsi Riau). J. Agromet. 24:23-32.

Yuniarti, M.A. Chozin, D. Guntoro, K. Murtilaksono. 2018. Perbandingan Arachis pintoi dengan jenis tanaman penutup tanah lain sebagai biomulsa di pertanaman kelapa sawit belum menghasilkan. J. Agron. Indonesia 46:215-221 